\title{
Musicologically Relevant Sources from the Manuscript Collection of the Parish Church of St. James in Brno
}

\author{
Lumír Škvařil / lumir.skvaril@gmail.com \\ Ústav hudební vědy, Filozofická fakulta, Masarykova univerzita, Brno, CZ
}

\begin{abstract}
There is an interesting collection of manuscripts from the parish church of St. James in Brno. This collection covers a continuous period from early years of the church in 13th century up to early modern time. The collection has been preserved relatively untouched up to these days which is important and quite rare fact. Today it contains 127 manuscripts which can be found in the Brno city archive. Naturally, most of them are liturgical books and many also contain musical notation. This paper aims to present those liturgical books of the collection, which are musicologically relevant. There are mainly missals, but also Psalters, breviaries and graduals can be found in the collection. Main expansion of the manuscript collection ended around 1500. By this time new printed books came into use.
\end{abstract}

\section{Key words}

Brno, St. James church, liturgical books, missal, psalter, breviary, gradual, polyphony collection 
The manuscript collection of the parish church of St. James in Brno $^{1}$ is a very well preserved book collection from an important church institution and so it gives us relatively rare insight into its history. In other collections, many books were added later and therefore their present state does not reflect their historical state. But in the case of the St. James manuscripts the situation is different. The collection meets the practical needs of a parish church and was being built from the early years of this church's existence in the 13th century. It was maintained and continuously extended. Its expansion ended around 1500, which could be also related to the coming of new printed books (which were used from the end of the $15^{\text {th }}$ century). Only few manuscripts were added to the collection after 1500 . Since then the collection has stayed more or less in a preserved state. Until the $20^{\text {th }}$ century the books were lying physically still in the building of St. James church. In 1931 the books were moved to the Brno city archive, where they have been accessible to the public up to now. There are several catalogues of this collection, first coming already from 1780 (put together by Alexius Habrich). ${ }^{2}$ The newest is the catalogue made by Stanislav Petr in 2007. ${ }^{3}$ Luckily, we also have another source - an inventory written in $1487 .{ }^{4}$ Comparing the present state with this inventory also helps us to estimate how well preserved the collection is.

In the musicological context, the work of František Pokorný is essential. Pokorný researched the St. James manuscripts and wrote a whole volume about them as a part of more volumes work on musical history of Brno until the beginning of the $15^{\text {th }}$ century. ${ }^{5}$ Besides this work František Pokorný also wrote a separate treatise about chronology of St. James missals. ${ }^{6}$

In total, the collection contains 127 manuscripts. 36 of them could be considered as musicologically relevant liturgical books (not all of them contain musical notation - that is, however, not the only parameter which is important). The most common type of book in the collection is a missal. Apart from missals there are also several breviaries, Psalters, graduals and two volumes of $16^{\text {th }}$-century polyphonic masses.

There are 18 handwritten missals in the collection. They cover a continuous period from the early years of the church in 13th century up to the coming of printed books at the end of the $15^{\text {th }}$ century. If we compare this number to what the inventory form 1487 says, we find a relatively good correspondence. In the inventory missals are listed, yet only summarized as one item - missalia xiiii. But from the 18 missals we have today we must subtract two books, which could not be there in 1487 - numbers 17 and 1/10.

1 Archiv města Brna (AMB), fond V 2 Svatojakubská knihovna.

2 Catalogus bibliothecae ecclesiae parochialis ad S. Iacobum Brunnae, confectus ab a. r. Patre Alexio Habrich OSB, antiquissimi ac celeberrimi monasterii Rayhradensis priore. Anno 1780. AMB Sign. V 2, st. sign. 7260, st. sign. U 20. (Quotation according to PETR 2007, s. LXI.)

3 PETR, Stanislav. Soupis rukopisů knihovny při farním kostele svatého Jakuba v Brně. Praha: Masarykův ústav a Archiv Akademie věd, 2007.

4 AMB, fond A 1/1 Sbírka listin, mandátů a listů, inv. č. 765, 26. October 1487 - 3. July 1489. Quotation according to a paper about this inventory BOROVSKÝ, Tomáš. Svatojakubská knihovna v Brně na konci 15. století. In Querite primum regnum dei. Sbornik přispěvků k poctě Jany Nechutové. Brno 2006, pp. 545-550.

5 POKORNÝ, František. Hudebni obraz Brna do počátku 15. století. I: Chorálni zpěv pod správou kostela jakubského. Brno: Archiv města Brna a Muzejní a vlastivědná společnost v Brně, 1991.

6 POKORNÝ, František - ed. ČERVENKA, Stanislav. Chronologie brněnských misálů sv. Jakuba, rukopisů v Archivu města Brna. Brno v minulosti a dnes, 2014, 27, pp. 313-370. 
Then we can also find another missal in the inventory on the next page among books for the St. Adauct altar (should be no. 9/12). Hence, we eventually have 16 vs. 15 books, which is quite satisfying. The actual vast amount of the missals is explained by the fact of various altars having their own missals. These came to the church mainly as donations, which are still documented in several cases (see tab. 1).

The oldest missal is the $13^{\text {th }}$ century plenarium no. 18 , which was probably the main book used for the mass chants at St. James church in its early years. Though it was

\begin{tabular}{|c|c|c|c|c|c|}
\hline \multirow[t]{21}{*}{ Missals } & Sig. & Century & Notation & Notes & Acquisition \\
\hline & 18 & 13. 2nd half & $\mathrm{Y}$ & $\begin{array}{l}\text { Cistercian plenarium, signs of } \\
\text { secular use }\end{array}$ & Copy from Oslavany source? \\
\hline & $6 / 11$ & 14. beginning & $\mathrm{Y}$ & $\begin{array}{l}\text { Diocesan plenarium Moravia. } \\
\text { Used at St. } \\
\text { Nicolaus chapel. } \\
\end{array}$ & \\
\hline & $8 / 14$ & 14. 2nd half & Y & $\begin{array}{l}\text { Probably monastic rite (accord- } \\
\text { ing to Pokorný) }\end{array}$ & $\begin{array}{l}\text { Not sooner then 15th 2nd half } \\
\text { from Zdechovice } \\
\text { (Pardubice) }\end{array}$ \\
\hline & $1 / 10$ & 14. 50' & $\mathrm{Y}$ & $\begin{array}{l}\text { Ordered from provost of St. } \\
\text { Peter (Nicolaus) }\end{array}$ & From St. Peter in Brno but later \\
\hline & $4 / 13$ & 14. end & $\mathrm{Y}$ & & $\begin{array}{l}\text { Dedication to St. Vitus altar } \\
\text { from Jan Sundlin } \\
\text { 1413. Later to St. Cecilia altar } \\
1418 \text { from Alžběta. }\end{array}$ \\
\hline & $9 / 12$ & ca 1400 & $N$ & $\begin{array}{l}\text { Sigismundi Knab Notarii } \\
\text { Brunensis }\end{array}$ & $\begin{array}{l}\text { Dedication to St. Felix and } \\
\text { Adauct altar from } \\
\text { Sigismund Knab ca } 1477\end{array}$ \\
\hline & $10 / 8$ & 15. beginning & $N$ & $\begin{array}{l}\text { Same decorations and calendar } \\
\text { as } 9 / 12\end{array}$ & $\begin{array}{l}\text { Dedication to St. Vitus altar in } \\
1413 \text { from Jan } \\
\text { Schwarz and Kunhuta } \\
\end{array}$ \\
\hline & $13 / 19$ & 15. beginning & $\mathrm{Y}$ & $\begin{array}{l}\text { Same decorations and calendar } \\
\text { as } 9 / 12\end{array}$ & \\
\hline & $11 / 21$ & 15. beginning & $N$ & $\begin{array}{l}\text { Same decorations and calendar } \\
\text { as } 9 / 12\end{array}$ & \\
\hline & $12 / 23$ & 15. beginning & $\mathrm{Y}$ & $\begin{array}{l}\text { Same decorations and calendar } \\
\text { as } 9 / 12\end{array}$ & \\
\hline & 15 & 15. 1st half & $Y$ & & \\
\hline & 7 & $15.20^{\prime}$ & $N$ & Hungarian influence & $\begin{array}{l}\text { Dedication to St. Philip and } \\
\text { Jacob altar in } 1423 \\
\text { from priest Oldřich }\end{array}$ \\
\hline & 6 & $15.30^{\prime}$ & $N$ & Hungarian influence & $\begin{array}{l}\text { Before } 1435 \text { from Nicolaus } \\
\text { lohannis from Brno, } \\
\text { deacon at St. James church }\end{array}$ \\
\hline & $5 / 9$ & 15. half & $\mathrm{Y}$ & Hungarian influence & \\
\hline & $7 / 22$ & 15. 2nd half? & $\mathrm{N}$ & & \\
\hline & $2 / 16$ & 15. 4th quarter & $Y$ & & \\
\hline & $3 / 20$ & 15. 4th quarter & $\mathrm{Y}$ & & \\
\hline & print & 1488 & $\mathrm{Y}$ & & 3 exemplars \\
\hline & 17 & 1491 & $\mathrm{Y}$ & & $\begin{array}{l}\text { Dedication from Jacob Scheim } \\
\text { and nun Marta, } \\
\text { Brno }\end{array}$ \\
\hline & print & 1499 & $\mathrm{Y}$ & & 3 exemplars \\
\hline
\end{tabular}

Tab. 1. Missals in the St. James collection. 
dedicated to the parish church, its rite is monastic, namely Cistercian. This can be easily explained as the female Cistercian monastery in Oslavany had patronage over St. James church until the $16^{\text {th }}$ century (1532). The second oldest item is the plenarium no. $6 / 11$, which already reflects the rite of Moravian diocese. It is likely that this missal was used at St. Nicolaus chapel which formerly stood at today's Liberty square (Náměstí Svobody). Then a list of missals follows which I will not describe separately. Some of the missals contain musical notation, some not (as visible in the table). Generally, the missals reflect the rite of the Moravian diocese (that means Olomouc diocese - hence the book can be marked as missale Olomucense). In three of the missals, Hungarian influence can be recognized. These are nos. 7, 6 and 5/9. They contain proper formulars to St. Stephen, Ladislaus and Emeric so they were most likely transcribed from a Hungarian missal. In addition, five missals nos. 9/12, 10/8,13/19,11/21 and 12/23 should be mentioned, because they have the same decorations, calendar and are of similar age. In two of them we even know the donors. Therefore we may assume these could be typical examples of Brno missals in the early $15^{\text {th }}$ century. The acquisition of new handwritten missals ends with the coming of printed ones. Just for illustration, I also added first printed missals used at St. James church into the table. First version of printed missale Olomucense obtained in 1488 is present in three exemplars. Then there are also three exemplars of the second version from 1499. It is interesting that even after the first incunabula came in 1488, another handwritten missal was made and donated to St. James church. This is an opulent missal no. 17 of 1491 and, the youngest handwritten missal of the collection. Its rite also reflects the Olomouc diocese. It should have probably been used by the altar of Virgin Mary and its donation was made by Jacob Scheim, who was a sacristan at St. James church in those times, and by a nun called Martha. Both of them have a small picture in the manuscript in the formulars of their patrons. And just as a curiosity the name of Jacob Scheim can also be found in the header of the inventory from 1487 (which is natural, as he was a sacristan).

Other types of books are not so numerous, but there are still Psalters, breviaries and graduals (tab. 2). Beside these chant books there are also two polyphonic collections from the $16^{\text {th }}$ century - but about them later.

Psalters probably reflect the existence of a school, which had already existed by St. James church in the $13^{\text {th }}$ century. Learning psalms was the main part of the education process at the school. There are 6 Psalters in the collection. Comparison with the inventory does not provide much information, since there we can only find a general item psalteria (we do not know, however, how many). Three of the Psalters are very old - from the $13^{\text {th }}$ century. None of them reflects the rite of Olomouc diocese. In the case of Psalter 17/37 we can see something similar as in the case of the oldest missal from St. James, no. 18 - this Psalter also shows signs of female Cistercian rite, so it must be connected with Oslavany monastery. Some of these Psalters contain notated parts, too - antiphons and hymns (fig. 1 shows folio $85 \mathrm{r}$ from the late 13th century Psalter no. 18/36 where psalmody antiphons can be seen). Similarly, as in the case of missals, by the end of the $15^{\text {th }}$ century Psalters were acquired in a printed form - we know there was for example a printed Psalter from 1499 (this one is no more present in the 
Psalters

\begin{tabular}{|l|l|l|}
\hline Sig. & Century & Notes \\
\hline $20 / 31$ & 13.1 st half & (Pokorný doesn't mention) \\
\hline $17 / 37$ & 13.2 nd half & Cistercian \\
\hline $18 / 36$ & 13.2 nd half & Notation; not Moravian diocese \\
\hline $19 / 27$ & 14. beginning & Notation \\
\hline $24 / 24$ & $14 .+15$. & Notation (later) \\
\hline $29 / 35$ & 1473 & \\
\hline
\end{tabular}

Breviaries

\begin{tabular}{|l|l|l|}
\hline Sig. & Century & Notes \\
\hline $23 / 32$ & 14. half & Notation; strong signs of Prague diocese \\
\hline $22 / 30$ & 14. end & \\
\hline 34 & 1393 & $\begin{array}{l}\text { Originally for Vyšehrad, at the end of 15th century } \\
\text { dedicated to St. James church (St. Wolfgang chapel) }\end{array}$ \\
\hline $25 / 28$ & 15. beginning & \\
\hline $26 / 25$ & 15. beginning & In mid 15th century property of priest in Týnec \\
\hline $27 / 29$ & 15. end & \\
\hline $28 / 26$ & 15. end & \\
\hline
\end{tabular}

Graduals

\begin{tabular}{|l|l|l|}
\hline Sig. & Century & Notes \\
\hline $21 / 33$ & ca 1300 & Diocesan gradual (Olomouc diocese) \\
\hline 1 & 1494 & Proprium de tempore et de sanctis \\
\hline 2 & 1493 & Ordinarium et sequences \\
\hline
\end{tabular}

Tab. 2. Psalters, breviaries and graduals in the St. James collection.

collection, but probably it is the one, which can be nowadays found in the Moravian library). ${ }^{7}$

Another present type of liturgical book is breviary. Overall, there are 7 breviaries in the collection. As we can see many of them are relatively young. Nos. 27/29 and 22/30 are from the late $15^{\text {th }}$ century and nos. 26/25 and 34 were acquired later. Thus only 3 or 4 of them can be accounted as parts of the inventory. In the inventory there are no breviaries at all. But there are three antiphonaries and antiphonaries are, on the other side, not present among the St. James manuscripts at all. Hence, the term antiphonary in the inventory must have designated breviary. In the list we can see items duo magna antiphonaria notata and then also one antiphonarium parvum. One of the two big books with notation must be no. $23 / 32$ because it is both big and notated. It is also the most interesting breviary from the musicological perspective. It is the only one with musical notation and it was analyzed by František Pokorný. ${ }^{8}$ The second big antiphonary from the inventory is either lost or it is no. 22/30 which is similarly big, but does not contain musical notation.

7 Psalterium Olomucense 1499. Moravská zemská knihovna, sign. PT3-0009.619.

8 POKORNÝ 1991, op. cit., pp. 98-126. 


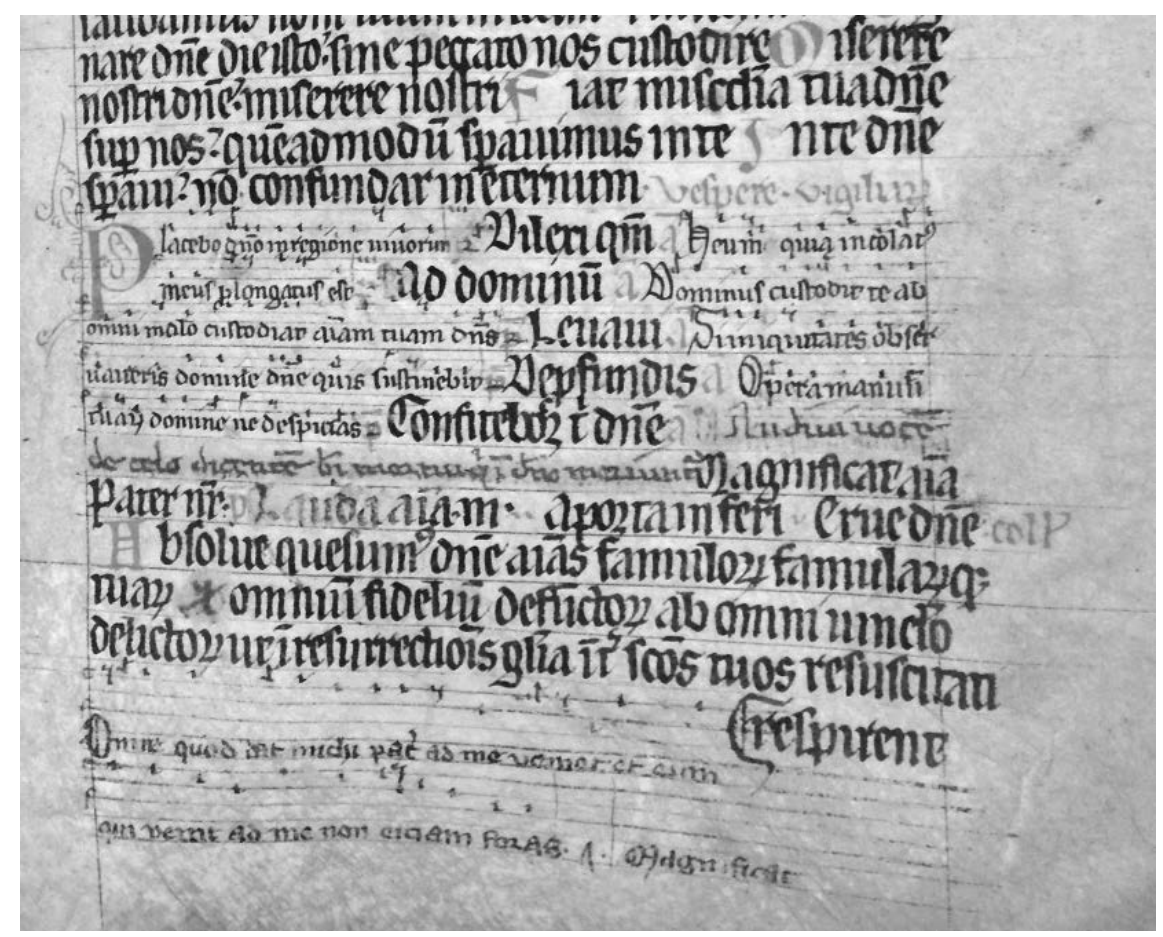

Fig. 1. AMB, V 2, Psalter no. 18/36, f. $85 \mathrm{r}$ - example of notated antiphons.

The last important type of book is gradual. In the collection we have three. Two of them are from the very end of the $15^{\text {th }}$ century. In the time when the inventory was written, only one of them could be there - no. 21/33. But the inventory mentions duo libri graduales, so the second one must have been lost. Gradual no. 21/33 came into the collection probably around 1300 and could be used as the major book for mass chants in those times and probably at least partially replaced the Cistercian plenarium no. 18. It was also analyzed by František Pokorný. ${ }^{9}$ Its content reflects the rite of Olomouc diocese. This gradual is also interesting due to its notation as it shows a messine notation in its development phase around 1300. In several cases old adiastematic neumes are used.

Finally, two volumes of gradual no. 1 and 2 must not be forgotten. These books date back to 1493 and 1494. Consequently, they cannot be recorded in the inventory. They are equipped with the same painted decorations as the youngest handwritten missal no. 17 dedicated by a sacristan Jacob Scheim and Marta, the nun. Although the identity of the donor is not so clear here, we at least know that Valentin Leuchtenzan, a citizen of Brno, contributed certain amount of money for the sake of the new gradual for St. James church. ${ }^{10}$ Numbers 1 and 2 suggest that these books are somehow significant -

$9 \quad$ Ibid., pp. 51-68.

10 BOROVSKÝ, Tomáš. „Zu der Ere Gots und meiner Sele zu Seligkeit“: Odkazy brněnských měštanů církevním institucím v letech 1410-1530. In Sbornik praci filozofické fakulty brněnské univerzity, C 46, 1999, pp. 79-96, zde 95. 
and they really are because physically they are definitely the biggest books of the collection. The format of both of the volumes is similar, just no. 2 is much thinner. The main gradual is in volume no. 1 - here we can find proprial texts for the whole year, both temporal and sanctoral parts. Volume no. 2 contains ordinaria and sequences (so it is actually kyriale and sequentiale). Unlike the missals, where using of manuscripts could have been suppressed by coming of prints, in the case of graduals it seems to be different. When I searched the list of early prints of St. James church, I found no graduals there. It seems they did not have a printed gradual. And manuscripts no. 1 and 2 show visible signs of practical using far into the modern age. They probably became the major books for mass chants at St. James church for many years. Later inscriptions can be found in both volumes, but here I am only going to mention those from the main gradual no. 1. In this gradual the inscriptions are on approximately 40 pages (from total of 536). These could be divided into several layers. Probably the oldest one is written on the front paste down. The scribe wrote here an order of morning votive masses for each day of the week. He made use of the fact, that the gradual's apertures are numbered so he also added a reference to each chant. Chants can be therefore easily found and the content of masses reconstructed (although some folios are missing). But even more interesting is the fact, that these inscriptions have a connection with other two notated manuscripts, which I have not properly treated in this text yet. These are two volumes of polyphonic masses no. $14 / 5$ and $15 / 4 .{ }^{11}$ Recently they have been standing in the centre of attention and also at this colloquium some papers were connected with them. Therefore I will not describe them at this point. But in this context the crucial discovery is the one of Vladimír Maňas who noticed that the hand, which wrote these inscriptions, probably belongs to the main scribe of both of the polyphonic volumes. ${ }^{12}$ They were written in the mid- $16^{\text {th }}$ century. This discovery shows that chant gradual no. 1 used to be used concurrently with the polyphonic collections. A chant from the gradual no. 1 could be the base and the polyphony might be employed for more festive masses. Another layer of inscriptions was written in ink by a younger hand. This hand wrote several references on the using of certain chants here, several retextings (contrafacts) and even three added chants - also with the melody. The case of contrafactum can be found for example on folios $12 \mathrm{v} / 13 \mathrm{r}$ - the usual text of introit for the $3^{\text {rd }}$ Sunday after Epiphany Adorate deum was alternatively replaced with the text for St. Michael and archangels. Only the incipit stays unchanged - instead of usual Benedicite dominum in St. Michael's text, here Adorate deum remains. This text to St. Michael is not new - it can already be found in the old neumed manuscripts, yet normally it is accompanied by a different melody. This text alternation is also mentioned in the rubric. One of the added chants, not present in the book since its origins, is shown on picture 2. This can be found on originally blank folio $174 \mathrm{v}-$ it is an introit to St. Ignatius, Martin and Francis. Here we can also see the notation which

11 These manuscripts are closely described in MAŇAS, Vladimír. Rukopisy renesanční polyfonie - zapomenutá a přitom cenná součást svatojakubské farní knihovny. Brno v minulosti a dnes, 2013, 26, pp. 39-49; and HORYNA, Martin - MAŇAS, Vladimír. Two mid-16th-century manuscripts of polyphonic music from Brno. Early music, 2013, 40, no. 4, pp. 553-575.

12 MAŇAS 2013, op. cit., pp. 44-45. 


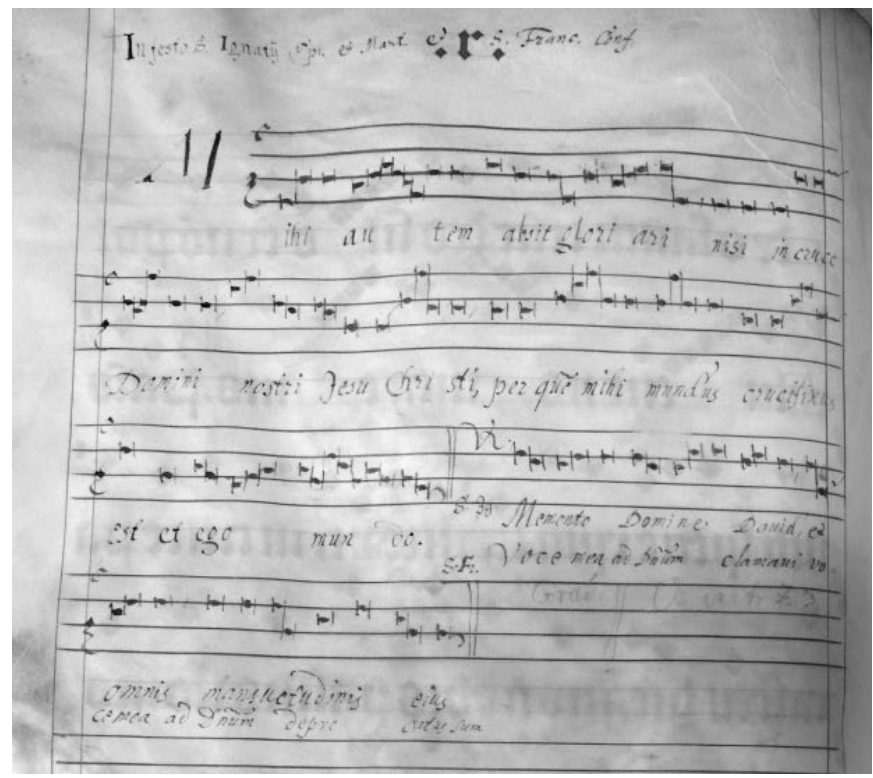

Fig. 2. AMB, V 2, Gradual no. 1, f. 174v - added introit to St. Ignatius, Martin and Francis.

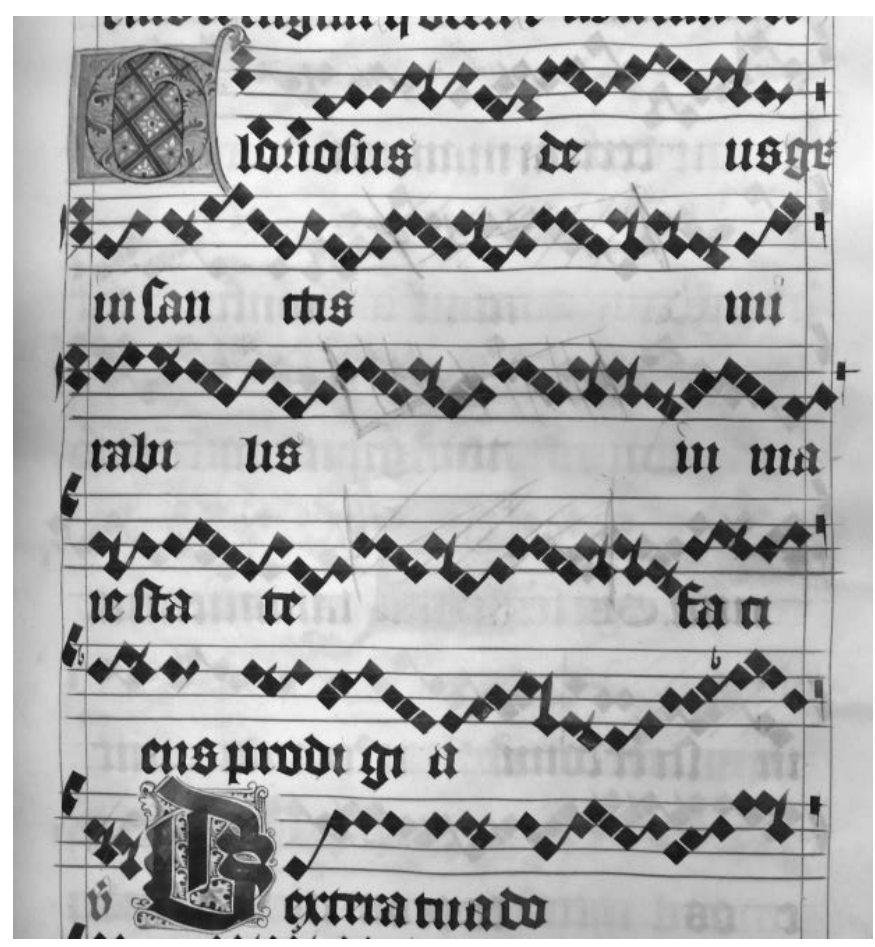

Fig. 3. $A M B, V 2$, Gradual no. 1, f. 227r - example of melisma shortening. 
had been used by this scribe. In the same picture next to the chant an example of the third, the youngest layer of the inscriptions, can be seen. These are written with a pencil and mark references to the chants which should be used (here Os justi and reference to the aperture Z 3), then various changes of the text - not just complete retextings but also minor issues, such as replacing several words - and finally also changes of the chant - typically shortening, especially shortened melismas. An example of this is for example on folio 227r (fig. 3). These inscriptions go far into the modern age. Still, as can be seen, they have a practical character and prove that this gradual was being used even a long time after its birth.

\section{Bibliography}

\section{Sources:}

Archiv města Brna (AMB) fond V 2 Svatojakubská knihovna. Signatures (Habrich; Gutmensch/ Habrich) 1, 2, 6, 7, 15, 17, 18, 34; 1/10, 2/16, 3/20, 4/13, 5/9, 6/11, 7/22, 8/14, 9/12, 10/8, $11 / 21,12 / 23,13 / 19,14 / 5,15 / 4,17 / 37,18 / 36,19 / 27,20 / 31,21 / 33,22 / 30,23 / 32,24 / 24$, $25 / 28,26 / 25,27 / 29,28 / 26,29 / 35$.

AMB, fond A 1/1 Sbírka listin, mandátů a listů, inv. č. 765, 26. October 1487 - 3. July 1489. (Quotation according to BOROVSKÝ 2006, s. 546.)

Catalogus bibliothecae ecclesiae parochialis ad S. Iacobum Brunnae, confectus ab a. r. Patre Alexio Habrich OSB, antiquissimi ac celeberrimi monasterii Rayhradensis priore. Anno 1780. AMB Sign. V 2, st. sign. 7260, st. sign. U 20. (Quotation according to PETR 2007, s. LXI.)

Moravská zemská knihovna, Psalterium Olomucense 1499, signature PT3-0009.619.

\section{Literature:}

BOROVSKÝ, Tomáš. „Zu der Ere Gots und meiner Sele zu Seligkeit“: Odkazy brněnských měštanů církevním institucím v letech 1410-1530. In Sbornik prací filozofické fakulty brněnské univerzity, C 46, 1999, pp. 79-96.

BOROVSKÝ, Tomáš. Svatojakubská knihovna v Brně na konci 15. století. In Querite primum regnum dei. Sbornik př́spěvků k poctě Jany Nechutové. Brno 2006, pp. 545-550.

HORYNA, Martin - MAŇAS, Vladimír. Two mid-16th-century manuscripts of polyphonic music from Brno. Early music, 2013, 40, no. 4, pp. 553-575.

MAŇAS, Vladimír. Rukopisy renesanční polyfonie - zapomenutá a přitom cenná součást svatojakubské farní knihovny. Brno v minulosti a dnes, 2013, 26, pp. 39-49.

PETR, Stanislav. Soupis rukopisů knihovny při farním kostele svatého Jakuba v Brně. Praha: Masarykův ústav a Archiv Akademie věd, 2007.

POKORNÝ, František. Hudebni obraz Brna do počátku 15. století. I: Chorální zpěv pod správou kostela jakubského. Brno: Archiv města Brna a Muzejní a vlastivědná společnost v Brně, 1991.

POKORNÝ, František - ed. ČERVENKA, Stanislav. Chronologie brněnských misálů sv. Jakuba, rukopisů v Archivu města Brna. Brno v minulosti a dnes, 2014, 27, pp. 313-370. 
